\title{
INTEGRASI TATA KELOLA KEBIJAKAN PEMBANGUNAN KELAUTAN BERKELANJUTAN
}

\author{
(Governance Management Policy Integration For Sustainable Marine Development)
}

\author{
Diah Apriani Atika Sari \\ Fakultas Hukum Universitas Sebelas Maret Surakarta \\ JI. Ir. Sutami No. 36 A, Kentingan Surakarta, 57126 \\ E-mail: atika_sari@staff.uns.ac.id
}

Naskah diterima: 13 Mei 2019; revisi: 29 Juli 2019; disetujui: 2 Agustus 2019

\begin{abstract}
Abstrak
Wilayah laut Indonesia memiliki makna yang sangat penting untuk pembangunan nasional. Data Kementerian Kelautan dan Perikanan mencatat potensi ekonomi kelautan mencapai Rp. 3000 triliun sementara yang baru digarap baru Rp. 291,8 triliun. Artinya, potensi nilai ekonomi kelautan belum dimanfaatkan dan dikelola secara maksimal. Pembangunan kelautan harus tepat sasaran berdasarkan pada pendekatan pembangunan yang berkelanjutan agar pemanfaatan laut dapat mencapai tujuannya yaitu untuk sebesar-besarnya bagi kemakmuran seluruh rakyat. Dengan demikian, diperlukan tata kelola yang baik dan berkelanjutan dari sektor ekonomi, sosial-budaya, serta politik, pertahanan dan keamanan untuk mendukung program pembangunan kelautan. Untuk mencapai tujuan tersebut, Pemerintah merumuskan dalam kebijakan kelautan Indonesia melalui Undang-Undang Nomor 32 Tahun 2014 Tentang Kelautan dan Peraturan Presiden Republik Indonesia Nomor 16 Tahun 2017 Tentang Kebijakan Kelautan Indonesia. Langkah penting selanjutnya adalah membuat program-program pembangunan kelautan Indonesia yang komprehensif dan terintegrasi untuk mewujudkan cita-cita Indonesia sebagai Poros Kelautan Dunia.
\end{abstract}

Kata Kunci: integrasi, tata kelola, kebijakan kelautan

\begin{abstract}
The Indonesian sea area has a very important meaning for the national development. Data from the Ministry of Maritime Affairs and Fisheries notes that the economic potential of the sea reaches $R p .3000$ trillion, while the current realization is only Rp. 291.8 trillion. This means that the potential of marine economic value has not been maximally utilized and managed. Marine development must be on target based on a sustainable development approach so that the use of the sea can achieve its objectives, as much as possible for the welfare of the people. Thus, it needs good and sustainable governance from the economic, socio-cultural, political, defense and security sectors to support marine development programs. To achieve this goal, Indonesian Government issues Indonesia's marine policy through Law No. 32 of 2014 concerning Marine and Presidential Regulation of the Republic of Indonesia Number 16 of 2017 concerning Indonesian Marine Policy. The next important step is to set up comprehensive and integrated Indonesian marine development programs to realize the purpose of Indonesia as the World Maritime Axis.

Keywords: integration, governance, marine policy
\end{abstract}




\section{A. Pendahuluan}

Indonesia sebagai negara kepulauan terbesar di dunia memiliki 17.504 pulau, 16.056 pulau diantaranya telah dibakukan dan didaftarkan ke Perserikatan Bangsa-Bangsa melalui sidang ke X United Nations Conference on Standardization of Geographical Names. ${ }^{1}$ Sumber kekayaan alam yang berlimpah menjadikan wilayah laut memiliki makna yang sangat penting untuk pembangunan nasional. Posisi strategis Indonesia tidak hanya dilihat dari posisi di persilangan antara dua benua, yaitu Asia dan Australia, serta dua samudera, yaitu Samudera Pasifik dan Samudera Hindia, tetapi juga di antara Laut China Selatan dan Laut Asia Timur dengan Samudera Hindia menempatkan Indonesia pada posisi penting dalam menciptakan stabilitas politik, ekonomi serta keamanan regional dan internasional. ${ }^{2}$

Dengan luas wilayah 8,3 juta $\mathrm{km}^{2}{ }^{3}$ serta posisi silang yang strategis menjadikan Indonesia berada tepat ditengah proses perubahan, baik secara geopolitik, geostrategis, dan geoekonomi. Geopolitik di Indonesia disebut dengan istilah Wawasan Nusantara. Pandangan geopolitik Indonesia berdasarkan pada pemikiran kewilayahan dan kehidupan bangsa Indonesia. ${ }^{4}$ Wawasan Nusantara mempunyai latar belakang, kedudukan, fungsi dan tujuan filosofis sebagai dasar pengembangan wawasan nasional Indonesia. Oleh karena itu Wawasan
Nusantara didefinisikan sebagai cara pandang bangsa Indonesia tentang diri dan lingkungan keberadaannya dengan memanfaatkan kondisi dan konstelasi geografi dengan menciptakan tanggung jawab, motivasi, dan rangsangan bagi seluruh bangsa Indonesia untuk mencapai tujuan nasional.

Dalam kaitannya dengan kehidupan bernegara dibutuhkan konsep geostrategis sebagai metode untuk mewujudkan cita-cita dan tujuan. ${ }^{5}$ Geostrategis merupakan suatu strategidalam memanfaatkan kondisigeografis negara dalam menentukan kebijakan, tujuan, dan sarana umum untuk mewujudkan cita-cita proklamasidantujuan nasional. Adapun tujuan geostrategis Indonesia adalah menyusun dan mengembangkan potensi kekuatan nasional, baik yang berbasis pada aspek ideologi, politik, sosial budaya, dan aspek-aspek alamiah sebagai upaya kelestarian, eksistensi hidup negara dan bangsa dalam mewujudkan cita-cita proklamasi serta tujuan nasional.

Sementara arah pemikiran dalam geoekonomi diartikan sebagai cara pandang mengenai permasalahan ekonomi bangsa yang ditinjau dari faktor geografi, baik kaitannya dengan lingkup regional, nasional maupun global. ${ }^{6}$ Sebagai negara kepulauan, laut Nusantara menyimpan potensi kekayaan perikanan yang sangat besar dan bernilai ekonomi tinggi. Data Kementerian Kelautan dan Perikanan mencatat potensi ekonomi 
kelautan mencapai Rp. 3000 triliun, sementara yang baru digarap baru Rp. 291,8 triliun. $^{7}$ Kekayaan alam kelautan yang berlimpah belum kita manfaatkan secara optimal untuk kesejahteraan masyarakat Indonesia.

Potensi pertumbuhan ekonomi kelautan merupakan peluang yang harus dikelola dan dimanfaatkan untuk menyejahterakan masyarakat. Dalam pembangunan ekonomi kelautan, Indonesia sedikitnya memiliki potensi di sebelas sektor ekonomi kelautan antara lain: 1) perikanan tangkap, 2) perikanan budidaya, 3) industri pengolahan perikanan, 4) industri bioteknologi, 5) kehutanan pesisir (coastal forestry), 6) pariwisata bahari, 7) energi sumber daya mineral, 8) perhubungan laut, 9) industri dan jasa kelautan, 10) sumber daya alam dan jasa-jasa lingkungan kelautan nonkonvensional seperti hidrat, bioenergi dari alga laut, deep sea water industries, energi laut (gelombang, pasang surut, dan ocean thermal energy conversion), dan bendabenda berharga asal muatan kapal tenggelam (harta karun di dasar laut), 11) sumber daya pulau-pulau kecil. $^{8}$

Perencanaan tersebut bersinergi dengan program Pemerintah yang tertuang dalam Peraturan Presiden Nomor 16 Tahun 2017 Tentang Kebijakan Kelautan Indonesia yang terdiri 7 pilar utama yang terdiri dari: 1) pengelolaan sumber daya kelautan dan pengembangan sumber daya manusia, 2) pertahanan, keamanan dan penegakan hukum, 3) tata kelola dan kelembagaan laut, 4) ekonomi dan infrastruktur kelautan dan peningkatan kesejahteraan masyarakat, 5) pengelolaan ruang laut dan perlindungan lingkungan laut, 6) budaya kelautan, dan 7) diplomasi kelautan. Dalam pembangunan kelautan, hal penting yang tidak dapat diabaikan dan harus mendapatkan fokus perhatian adalah kepedulian terhadap kesejahteraan masyarakat lokal dan kelestarian lingkungan sehingga pembangunan tidak hanya bertujuan untuk mendapatkan keuntungan sebesa-besarnya tanpa mempedulikan prinsip pembangunan berkelanjutan (sustainable development). Sehingga pertumbuhan ekonomi di bidang kelautan diwujudkan melalui pembangunan berkelanjutan yang efisien, bernilai tambah, inklusif dan inovatif sebagai penunjang aktivitas ekonomi.

Sebagai negara kepulauan yang bercirikan Nusantara, Indonesia telah menjadi negara pihak dalam United Nations Convention on the Law of the Sea (UNCLOS) 1982 melalui ratifikasi Undang-Undang Republik Indonesia Nomor 17 Tahun 1985 sehingga Indonesia mempunyai kedaulatan dan hak berdaulat atas beberapa wilayah laut. Kedaulatan penuh terhadap wilayah laut terdiri atas perairan pedalaman, perairan kepulauan dan laut teritorial mencakup dasar laut dan seisinya, serta ruang udara dari wilayah perairan tersebut. Selain hal tersebut, Indonesia juga memiliki hak berdaulat dan kewenangan tertentu di kawasan yurisdiksi Indonesia, antara lain atas zona tambahan, zona ekonomi eksklusif dan landas kontinen.

Lihat "Laporan Kinerja Kementerian Kelautan dan Perikanan”, Kementerian Kelautan dan Perikanan Republik Indonesia, 2016.

8 Rokhmin Dahuri, Makalah berjudul “Road Map Pembangunan Kelautan Untuk Mengembangkan Daya Saing dan Pertumbuhan Ekonomi Berkualitas Menuju Indonesia Yang Maju, Adil-Makmur, dan Berdaulat” disampaikan pada acara Simposium Nasional Jalan Kemandirian Bangsa, 2014. 
Dalam konteks tata kelola kebijakan pengelolaan dan pemanfaatan wilayah dan aktifitas di laut Indonesia, masih banyak tumpang tindih kebijakan yang berpotensi menimbulkan konflik vertikal dan horizontal, semisal belum adanya revisi Undang-Undang Republik Indonesia Nomor 1 Tahun 1973 Tentang Landas Kontinen. Undang-Undang No. 1 Tahun 1973 mengatur mengenai eksplotasi dan eksplorasi dasar laut hanya pada kedalaman 200 meter. Sementara Indonesia sebagai negara pihak dalam UNCLOS 1982 (ratifikasi UU No, 17 Tahun 1985) mengakui dan mengikatkan diri pada pengaturan landas kontinen sebagai kelanjutan alamiah daratan wilayah sampai jarak 200 mil laut dan dalam hal tertentu dapat mencapai 350 mil laut. Praktek yang dilakukan Indonesia antara lain dengan mengajukan submisi perpanjangan landas kontinen pada tahun 2008 ke Komisi Batas Kontinen Perserikatan Bangsa-Bangsa (PBB). Hasilnya Komisi Batas Kontinen PBB menyetujui untuk memberikan hak pengelolaan landas kontinen di luar 200 mil laut di barat laut Sumatera. Dengan demikian, UNCLOS 1982 tentunya memberikan keuntungan yang sangat besar bagi Indonesia, namun di sisi lain persoalan yang dihadapi dalam pengaturan landas kontinen adalah masih dipertahankannya rumusan lama dalam peraturan nasional. Undang-Undang No. 1 Tahun 1973 tentang Landas Kontinen yang berpedoman pada Konvensi Hukum Laut 1958 dalam beberapa hal sudah tidak sesuai dengan ketentuan Konvensi Hukum Laut 1982. Oleh sebab itu perlu adanya revisi UndangUndang No. 1 Tahun 1973 untuk memberikan kepastian hukum mengenai pengaturan landas kontinen dan mengamankan kepentingan Indonesia di laut.

\section{B. Metode Penelitian}

Penelitian ini merupakan penelitian hukum normatif, yaitu penelitian doktrinal berdasarkan bahan-bahan hukum primer dan sekuder. Pendekatan yang digunakan dalam penelitian ini adalah pendekatan perundangundangan (statue approach) dan pendekatan konseptual (conseptual approach). ${ }^{9}$ Pendekatan perundang-undangan adalah pendekatan dengan menggunakan legislasi dan regulasi. Pendekatan konseptual beranjak dari pandangan-pandangan dan doktrin-doktrin yang berkembang di dalam ilmu hukum. Pengumpulan bahan hukum menggunakan studi kepustakaan (library research) sementara analisis bahan hukum dilakukan secara kualitatif nonpositivistik menggunakan metode interpretasi. Interpretasi memperhatikan sinkronisasi teks maupun konteks hukum secara vertikal maupun horisontal terhadap peraturan perundang-undangan yang terkait.

\section{Pembahasan}

\section{Arah Pembangunan Kelautan Indonesia}

Wilayah laut beserta sumber daya alam yang terkandung di dalamnya merupakan aset penting dan prime mover pembangunan kelautan Indonesia, karena wilayah ini 
didukung tiga komponen utama yaitu: ${ }^{10} 1$ ) komponen biofisik dengan luas perairan \pm 5.87 juta $\mathrm{km}^{2}$ dengan garis pantai yang membentang $\pm 81.000 \mathrm{~km}^{2}$ menyebar di 17. 504 pulau dan memiliki potensi sumber daya yang melimpah, 2) komponen sosial ekonomi; sebagian besar penduduk Indonesia hidup di wilayah pesisir, 3) komponen sosial politik; banyaknya kebijakan politik yang secara langsung memberikan peluang bagi pembangunan kelautan Indonesia.

Sejarah telah mencatat kebesaran masa Ialu Kerajaan Sriwijaya dan Kerajaan Majapahit yang memiliki kekuatan kelautan besar dan sangat disegani serta diperhitungkan oleh bangsalain, memberikan pelajaran bagibangsa kita untuk mengembalikan kembali kekuatan dan kejayaan dengan mengoptimalkan potensi kelautannya. Bukti nenek moyang bangsa Indonesia telah menguasai lautan Nusantara bahkan mampu mengarungi samudera luas hingga ke pesisir Madagaskar dan Afrika bukan hanya pada penguasaan secara de facto namun juga penguasaan secara de jure. Sumpah Amukti Palapa dari Mahapatih Gajah Mada merupakan manifestasi Indonesia sebagai bangsa kelautan yang kuat. Namun setelah mencapai puncak kejayaan, Indonesia mengalami kemunduran saat masa penjajahan kolonial Belanda. Pasca kemerdekaan, Indonesia berusaha untuk membangkitkan kembali kejayaan kelautan Nusantara.

Tiga peristiwa yang menjadi pilar utama dalam pembangunan kelautan dalam memperkukuh keberadaan Indonesia sebagai negara merdeka dan didasarkan atas negara kepulauan sehingga mendapatkan pengakuan dari dunia internasional, yaitu: Pertama, Indonesia sebagai kesatuan bangsa (1928). Indonesia sebagai kesatuan bangsa telah dibangun saat Ikrar Sumpah Pemuda didegungkan pada Kongres Pemuda II tanggal 27-28 Oktober 1928 di Batavia (Jakarta). Sumpah Pemuda merupakan tonggak sejarah pergerakan untuk menegaskan cita-cita kemerdekaan dan berdirinya Indonesia. Sumpah Pemuda juga menegaskan identitas Indonesia dalam wujud satu bangsa, satu tanah air dan satu bahasa. Kedua, Indonesia sebagai kesatuan kenegaraan (1945). Indonesia memproklamasikan kemerdekaannya pada tanggal 17 Agustus 1945, artinya rakyat Indonesia menyatakan hidup dalam satu negara yaitu Negara Kesatuan Republik Indonesia dan tidak mungkin ada negara lain dalam NKRI.

Ketiga, Indonesia sebagai kesatuan kewilayahan (1957). ${ }^{11}$ Sebelum lahirnya DekIrasi Djuanda 1957, wilayah NKRI ketika merdeka meliputi wilayah bekas Hindia Belanda berdasarkan ketentuan dalam "Territoriale Zee en Kelautane Kringen Ordonantie" tahun 1939, yang menyatakan bahwa laut teritorial hanya sejauh 3 mil dari garis pantai ketika surut terendah dengan asas pulau demi pulau secara terpisah-pisah. Hal ini menyebabkan adanya "laut bebas" yang mengelilingi pulau-pulau Indonesia sehingga

10 Laporan Tim Harmonisasi Kementerian PPN/Bappenas, Departemen Kelautan dan Perikanan dan Departemen Hukum dan Hak Asasi Manusia bekerjasama dengan Mitra Pesisir, "Menuju Harmonisasi Sistem Hukum Sebagai Pilar Pengelolaan Wilayah Pesisir Indoensia", 2005.

1113 Desember 1957 Perdana Menteri Djuanda Kartawidjaja mengeluarkan pernyataan (deklarasi) selanjutnya disebut Deklarasi Djuanda yang berisi mengenani Wilayah Perairan Negara Republik Indonesia. Isi Deklarasi Djuanda sebagai berikut: "Bentukgeografi Indonesia sebagaisuatu Negara Kepulauanyangterdiridariberibu-ribu 


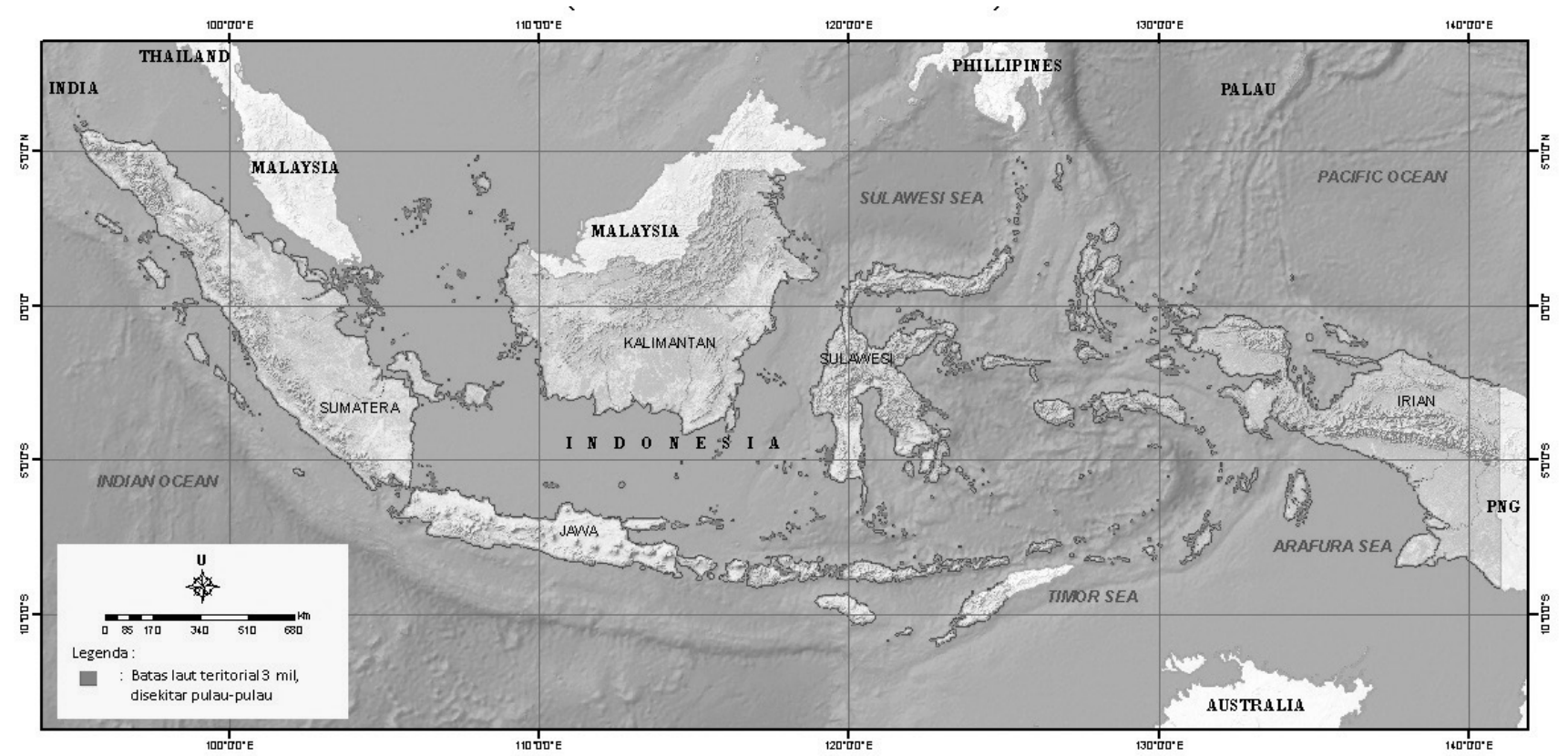

Gambar 1. Peta Wilayah Indonesia Sebelum Deklarasi Djuanda Berdasarkan TZMKO 1939 (Sumber: big.go.id)

menyulitkan dalam menjaga keutuhan dan keamanan Negara Kesatuan Republik Indonesia.

Deklarasi Djuanda memberikan harapan untuk mengembalikan kejayaan bangsa Indonesia sebagai bangsa kelautan dalam kesatuan wilayah Negara Kesatuan Republik Indonesia. Deklarasi Djuanda kemudian dikukuhkan menjadi Undang-Undang Nomor 4/Prp Tahun 1960 Tentang Perairan Indonesia. Wilayah Republik Indonesia yang semula sekitar 2 juta $\mathrm{km}^{2}$ (daratan) berkembang menjadi sekitar 5,1 juta $\mathrm{km}^{2}$ yang meliputi wilayah daratan dan lautan. Dalam hal ini, terjadi penambahan luas sebesar 3,1 juta $\mathrm{km}^{2}$, dengan laut teritorial sekitar 0,3 juta $\mathrm{km}^{2}$ dan perairan laut Nusantara sekitar 2,8 juta km².

Konsep Nusantara kemudian dituangkan menjadi Wawasan Nusantara. Setelah melewati perjalanan yang panjang konsepsi Wawasan Nusantara mendapat pengakuan dunia internasional dengan dimasukkannya pengaturan mengenai negara-negara kepulauan (archipelagic states) dalam UNCLOS 1982. Selanjutnya Indonesia meratifikasi UNCLOS 1982 melalui Undang-Undang Nomor 17 Tahun 1985. Setelah meratifikasi UNCLOS 1982 luas wilayah perairan laut Indonesia

pulau mempunyai corak tersendiri. Bagi keutuhan territorial dan untuk melindungi kekayaan Negara Indonesia semua kepulauan serta laut terletak diantaranya harus dianggap sebagai kesatuan yang bulat. Penentuan batas laut territorial seperti termaktub dalam Territorieale Zeen en Maritieme Kringen Ordonnantie 1939 Pasal 1 ayat (1) tidak sesuai lagi dengan pertimbangan di atas karena membagi wilayah daratan Indonesia dalam bagianbagian terpisah dengan territorialnya sendiri-sendiri. Berdasarkan pertimbangan-pertimbangan itu maka Pemerintah menyatakan bahwa segala perairan di sekitar, di antara, dan yang menghubungkan pulau-pulau yang termasuk Negara Indonesia dengan tidak memandang daratan Negara Indonesia dan dengan demikian bagian daripada wilayah pedalaman atau Nasional yang berada di bawah kedaulatan mutlak Indonesia. Lalu lintas yang damai diperairan pedalaman bagi kapal-kapal asing dijamin selamat dan sekedar tidak bertentangan dengan/mengganggu kedaulatan dan keselamatan Negara Indonesia. Penentuan batas laut territorial yang lebarnya 12 mil diukur dari garis-garis yang menghubungkan titik-titik ujung terluar pada pulau-pulau Negara Indonesia" 


\section{R duknal HTSVINDING}

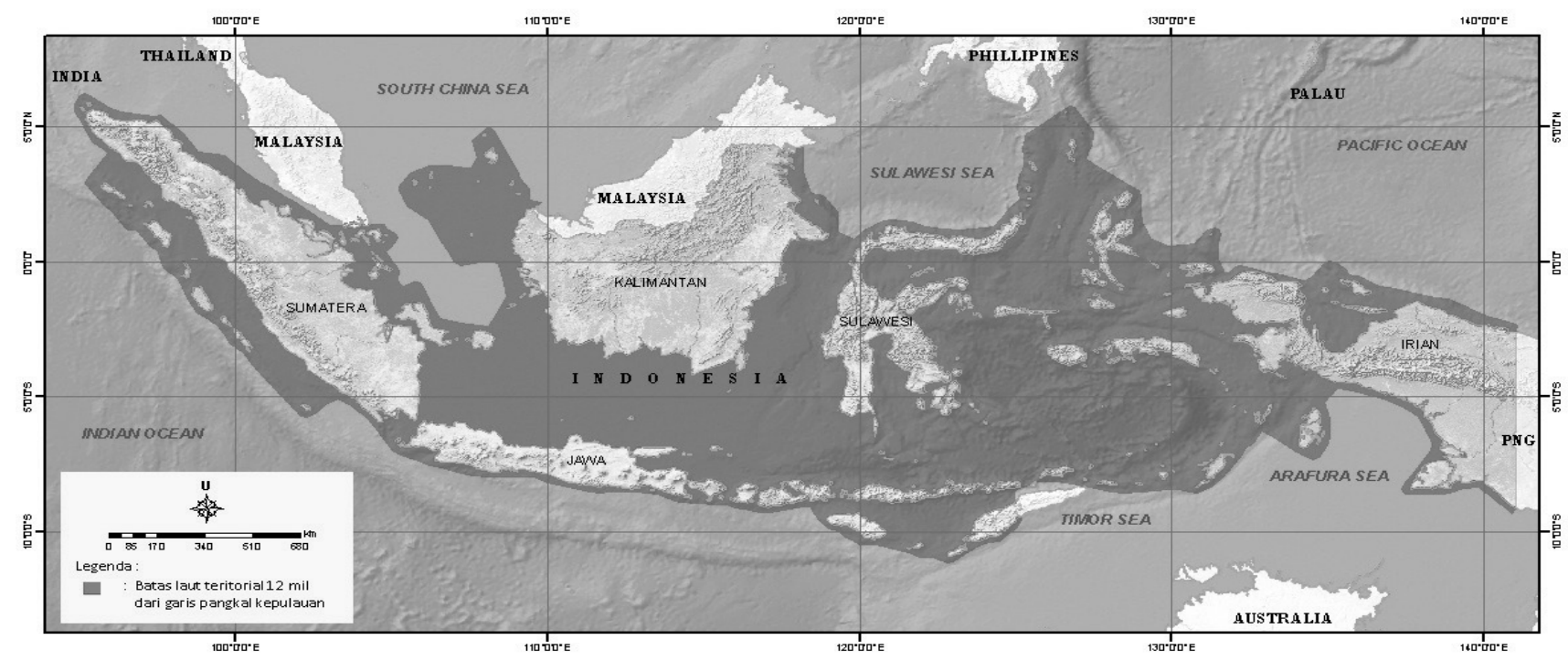

Gambar 2. Peta Wilayah NKRI Berdasarkan Deklarasi Djuanda 1957 (Sumber: big.go.id)

bertambah sekitar 2,7 juta $\mathrm{km}^{2}$, sehingga menjadi sekitar $5,81 \mathrm{~km}^{2}$.

Meskipun Indonesia mendapatkan penambahan luas yang cukup signifikan dalam penguasaan wilayah laut, kenyataannya potensi kelautan kita belum dikelola dan dimanfaatkan secara maksmial untuk pembangunan nasional. $\mathrm{Hal}$ ini tentunya mempengaruhi Indonesia dalam kontelasi geopolitik, geostrategis dan geoekonomi

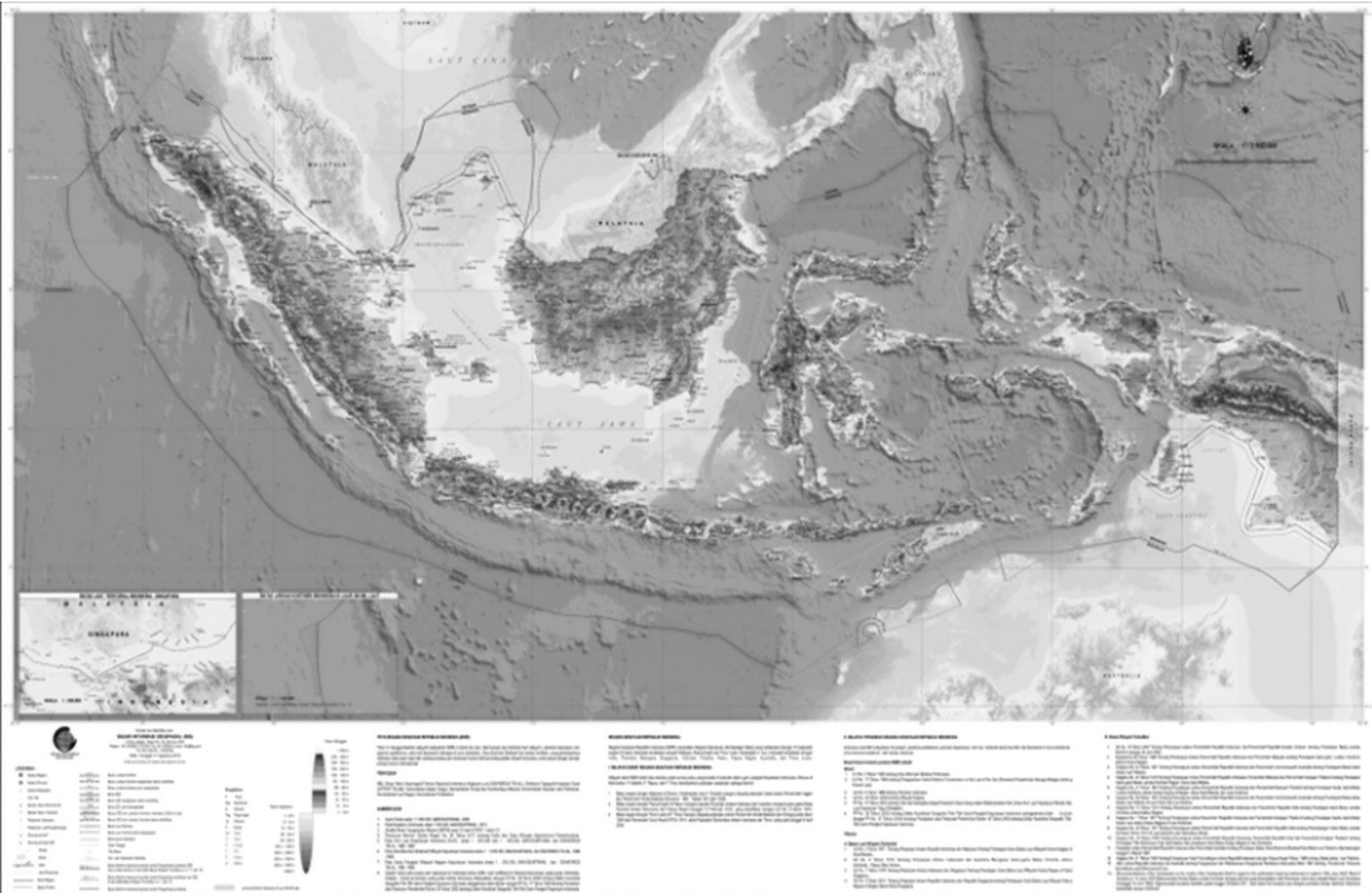

Gambar 3. Peta NKRI Berdasarkan UNCLOS 1982 (Sumber: big.go.id) 
global. Oleh karena itu, Indonesia harus merubah paradigma pembangunan dari land based development menjadi ocean-based development.

Dalam forum KTT Rio+20 di Brasil wacana ekonomi hijau sangat berkembang, namun Indonesia yang pada masa itu dipimpin Presiden Susilo Bambang Yudoyono mencanangkan ekonomi biru sebagai arah pembangunan nasional. Sementara banyak negara berorientasi pada pentingnya ekonomi hijau yang ramah lingkungan, Indonesia mengambil peluang untuk mengembangkan ekonomi biru sebagai pembangunan ekonomi kelautan. ${ }^{12}$ Pada era Presiden Susilo Bambang Yudhoyono aspek kelautan Nusantara mulai ditonjolkan secara sistematis, semisal strategi untuk mengangkat potensi pariwisata Indonesia ke kancah internasional melalui pesta rakyat berupa Indonesia Sail yang diadakan setiap tahun di lokasi yang berbeda-beda. Di akhir masa pemerintahan Yudhoyono, Undang-Undang Nomor 32 Tahun 2014 Tentang Kelautan berhasil disahkan oleh DPR.

Adanya kemajuan dalam bidang kelautan di era SBY memberi daya dukung yang kuat untuk pemerintahan selanjutnya. Presiden Joko Widodo dengan mantap menyatakan visi kekelautanan sebagai bagian utama pemerintahnnya. Dalam KTT Asia Timur, 13 November 2014, Presiden Jokowi menyatakan adanya lima pilar pembangunan Indonesia sebagai Poros Kelautan Dunia. Begitu pula di depan forum G-20 yang merupakan kelompok ekonomi dunia, Jokowi menyatakan bahwa Indonesia akan mengoptimalkan pemanfaatan potensi laut Indonesia dengan ekonomi kelautan.

Dalam langkah mengimplementasikan visi Poros Kelautan Dunia, percepatan pembangunan kelautan merupakan keniscayaan yang harus diupayakan dalam kerangka menyejahterakan rakyat Indonesia. Untuk mencapai tujuan tersebut, Pemerintah merumuskan dalam kebijakan kelautan Indonesia melalui Undang-Undang Nomor 32 Tahun 2014 Tentang Kelautan dan Peraturan Presiden Republik Indonesia Nomor 16 Tahun 2017. Visi kelautan Indonesia adalah mewujudkan Indonesia menjadi Poros Kelautan Dunia, yaitu menjadi sebuah negara kelautan yang maju, berdaulat, mandiri, kuat, serta mampu memberikan kontribusi positif bagi keamanan dan perdamaian kawasan dan dunia sesuai dengan kepentingan nasional.

Kebijakan Kelautan Indonesia terdiri atas 7 (tujuh) pilar, yaitu: 1) Pengelolaan sumber daya kelautan dan pengembangan sumber daya manusia; 2) Pertahanan, Keamanan, Penegakan Hukum, dan Keselamatan di Laut; 3) Tata kelola dan kelembagaan laut; 4) Ekonomi dan infrastruktur kelautan dan peningkatan kesejahteraan; 5) Pengelolaan ruang laut dan perlindungan lingkungan laut; 6) Budaya Bahari; dan 7) Diplomasi Kelautan. Untuk Rencana Aksi Kebijakan Kelautan secara sistematik dijabarkan ke dalam 5 (lima) kluster program prioritas, yang dapat digambarkan sebagai berikut:

\footnotetext{
Ade Prasetia, Ekonomi Kelautan Indonesia, (Yogyakarta: Diandra Kreatif, 2016), hlm. 41-46.
} 


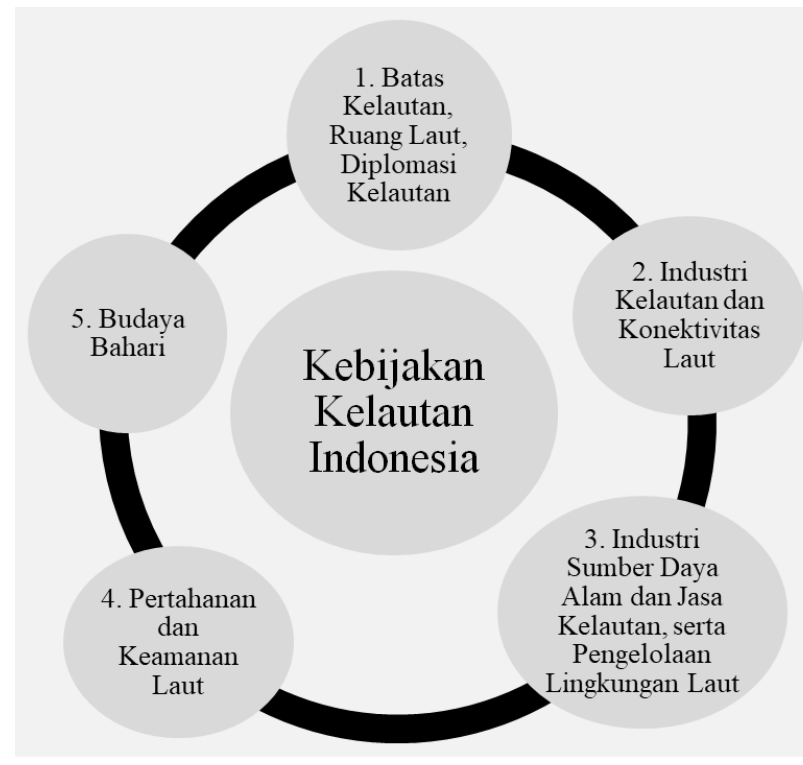

Gambar 4. Program Prioritas Rencana Aksi Kebijakan Kelautan Indonesia

\section{Integrasi Tata Kelola Kebijakan Pembangunan Kelautan Berkelanjutan}

Pembangunan kelautan harus diarahkan pada prinsip pembangunan berkelanjutan (sustainable development). Pembangunan yang memenuhi kepentingan hidup generasi saat ini tanpa mengabaikan kepentingan generasi mendatang untuk hidup dan memenuhi kebutuhannya atas lingkungan hidupdansumberdayakelautan. Pembangunan kelautan Indonesia dilaksanakan sebagai bagian dari pembangunan nasional untuk mewujudkan Indonesia menjadi negara kepulauan yang mandiri, maju, kuat dan berbasiskan kepentingan nasional. ${ }^{13}$

Salah satu langkah yang harus dilakukan adalah menyusun konstruksi kebijakan pembangunan kelautan. Untuk mewujudkan pembangunan kelautan yang komprensif dapat dilakukan melalui pendekatan; sosial budaya, ekonomi, serta politik, pertahanan dan keamanan. Pendekatan pertama yaitu sosial budaya. Pentingnya pendekatan sosial budaya didasarkan pada proses pengkajian pengenalan bangsa Indonesia sebagai negara maritim dan bangsa pelaut yang berpandangan bahwa laut merupakan potensi yang dapat dimanfaatkan untuk kesejahteraan masyarakat. ${ }^{14}$ Aspek sosial budaya sebagai bangsa maritim akan menempatkan Indonesia untuk tidak melepaskan akar sejarahnya sehingga sistem pembelajaran sebagai bangsa maritim harus ditanamkan sejak dini pada generasi muda mulai tingkat terendah sampai tertinggi. Sistem pembelajaran budaya maritim terutama generasi muda bertujuan untuk mengenalkan dan menanamkan potensi serta kekuatan bangsa. Pembelajaran dimulai dengan mengenalkan jati diri bangsa dan bagaimana kehidupan sebagai bangsa maritim dengan memasukkan ke dalam kurikulum baik di tingkat dasar sampai perguruan tinggi. Materi pembelajaran dirancang dengan memberikan muatan budaya maritim serta potensi kelautan Indonesia. Selain itu untuk penguatan budaya maritim diperlukan juga dorongan dari Pemerintah untuk membangun perguruan tinggi berbasis maritim. Dengan demikian restorasi budaya maritim akan berkesinambungan dan diharapkan generasi muda memiliki kesadaran untuk menempatkan kepentingan laut dalam pembangunan nasional. Sehingga sebagai negara maritim, rakyat Indonesia menyakini bahwa laut merupakan sumber kekayaan, sarana pemersatu bangsa, media diplomasi, 
media perhubungan, serta media pertahanan dan keamanan.

Kedua, pendekatan ekonomi. Kebijakan ekonomi kelautan bertujuan untuk menjadikan laut sebagai prime mover pembangunan ekonomi untuk meningkatkan kesejahteraan masyarakat. Kelautan menjadi faktor penting untuk mendukung pembangunan dari sektor ekonomi sehingga Indonesia perlu mengubah paradigma dari land based development menjadi ocean-based development yaitu wawasan dan pola pikir yang memandang potensi pembangunan tidak hanya bersumber dari darat (land based) tetapi juga dari laut (ocean based). Pembangunan kelautan melalui paradigma ocean based development memerlukan landasan konseptual dan legalitas yang jelas untuk pembangunan nasional. Landasan konseptual dalam pembangunan kelautan dimulai dengan menentukan arah pengelolaan sumber daya secara optimal sesuai dengan potensi yang ada. Pada prinsipnya, Pemerintah harus mendorong semua elemen di dalam masyarakat untuk menciptakan produkunggulanyang komparatif dan kompetitif baik di pasar nasional dan internasional. Langkah berikutnya diperlukan internaslisasi dalam kehidupan masyarakat Indonesia melalui ideologi kerakyatan yang digali dan dikembangkan dari Ideologi Pancasila. ${ }^{15}$ Sementara itu landasan legalitas memberikan landasan hukum dan perangkat kebijakan dalam pengelolaan sumber daya kelautan yang terarah dan terencana untuk pembangunan kelautan nasional.

Untuk percepatan pembangunan diupayakan melalui peningkatan peran, potensi, dan peluang sektor kelautan berkelanjutan. Untuk itu diperlukan peraturan perundang-undangan dan kebijakan sebagai pedoman dalam melakukan perencanaan, pelaksanaan serta monitoring pembangunan kelautan. Kebijakan ekonomi kelautan yang dapat diterapkan adalah melalui pendekatan ekonomi biru (blue economy) guna mendorong pemanfaatan dan pengusahaan sumber daya kelautan secara optimal dan berkelanjutan. Kebijakan ekonomi biru merupakan model pembangunan ekonomi yang mengintegrasikan pembangunan darat dan laut dengan memperhitungkan daya dukung sumber daya dan lingkungan. Potensi darat, laut dan udara harus disinergikan sehingga menjadi kekuatan Indonesia. ${ }^{16}$ Oleh sebab itu dalam pembangunan yang berbasis kebijakan ekonomi biru membutuhkan kebijakan untuk menciptakan sistem tata kelola kelautan yang komprehensif, terintegrasi, efektif dan efisien. Perangkat peraturan perundangundangan serta kebijakan harus selaras agar dapat diimpelentasikan dalam pembangunan kelautan Indonesia. Untuk memberikan arahan dalam pembangunan kelautan, Pemerintah telah mengeluarkan peraturan perundang-undangan, antara lain: UndangUndang Nomor 32 Tahun 2014 Tentang Kelautan, serta Peraturan Presiden Republik Indonesia Nomor 16 Tahun 2017 Tentang Kebijakan Kelautan Indonesia.

Ketiga, pendekatan politik, pertahanan dan keamanan. Bagi bangsa Indonesia, laut merupakan bagian integral dari wilayah negara yang tidak dapat dibagi-bagi, tetapi bisa dibedakan menurut rezim yang mengatur

15 Singgih Tri Sulistiyono, "Paradigma Maritim Dalam Membangun Indonesia: Belajar dari Sejarah", Lembaran Sejarah, Volume 12 Nomor 2 Oktober 2016, hlm. 101-102.

16 Lampiran I Peraturan Presiden Republik Indonesia Nomor 16 Tahun 2017 Tentang Kebijakan Kelautan Indonesia. 
sebagaimana diatur dalam UNCLOS 1982. Posisi silang Indonesia yang terletak diantara benua Asia dan Australia serta diantara Samudera Pasifik dan Samudera Hindia dipengaruhi kondisi konstelasi geografis Indonesia sebagai negara kepulauan. Posisi strategis ini juga berpengaruh pada kondisi politik, ekonomi, dan keamanan Indonesia.

Selanjutnya terkait dengan keamanan kelautan kawasan Asia Tenggara, ada beberapa permasalahan yang harus dihadapi dan memerlukan kerjasama untuk mengatasi permasalahan tersebut, antara lain: konflik perbatasan karena tumpang tindih klaim atas wilayah laut, pembajakan (sea piracy and armed robbery), terorisme, kejahatankejahatan transnasional (transnational organized crimes), keamanan pelayaran, dan perlindungan lingkungan laut. Dalam perspektif kepentingan nasional, tantangan yang dihadapi Indonesia adalah menjaga keamanan wilayah laut Indonesia dari ancaman kekuatan asing, antara lain: konflik perbatasan, potensi ancaman terorisme kelautan di choke point, berbagai kegiatan illegal fishing, illegal logging, illicit small arms trafficking, illicit, people trafficking, illicit drugs trafficking, smuggling, permasalahan lingkungan hidup. Dengan kata lain permasalahan keamanan domestik juga merupakan permasalahan yang terjadi di kawasan Asia Tenggara. Untuk mewujudkan keamanan laut diperlukan upaya penegakan kedaulatan dan penegakan hukum. ${ }^{17}$ Keamanan laut merupakan rangkaian mulai dari persepsi atau pemahaman segenap komponen bangsa, struktur organisasi, serta prosedur dan mekanisme penyelenggaraan keamanan yang memiliki kewenangan dalam penegakan kedaulatan dan penegakan hukum di laut. Untuk memperkuat penegakan hukum di laut beberapa badan telah dibentuk dalam menyelesaikan tumpang tindih kewenangan. Badan penegak hukum tersebut antara lain: 1) Forum Koordinasi Penanganan Tindak Pidana Perikanan yang dibentuk oleh KKP, 2) Satuan Tugas Perencanaan, Pengembangan Keamanan dan Penegakan Hukum di Laut yang dibentuk oleh Menteri Koordinator Bidang Politik, Hukum, dan Keamanan, 3) Bakorkamla. Saat ini Pemerintah membentuk Satgas 115 melalui Peraturan Presiden Republik Indonesia Nomor 115 Tahun 2015 Tentang Satuan Tugas Pemberantasan Penangkapan Ikan Secara llegal (Illegal Fishing) yang bertugas untuk memobilisasi kapasitas operasional KKP, Angkatan Laut, Polisi Nasional, Jaksa Penuntut Umum, Bakamla, dan instansi terkait lainnya.

Konsep tata kelola pembangunan kelautan dibangun berdasarkan tujuh pilar, yaitu: perhubungan laut, perikanan, wisata bahari, industri kelautan, energi dan sumberdaya mineral, bangunan laut dan jasa kelautan. Setidaknya terdapat lima peraturan perundang-undangan yang menjadi payung hukum utama pelaksanaan kebijakan pembangunan kelautan nasional, antara lain: (1) Undang-Undang Nomor 17 Tahun 1985 Tentang Pengesahan UNCLOS; (2) UndangUndang Nomor 6 Tahun 1996 Tentang Perairan Indonesia; (3) Undang-Undang Nomor 31 Tahun 2004 yang Diubah Dengan UndangUndang Nomor 45 Tahun 2009 Tentang Perikanan; (4) Undang-Undang Nomor 27 Tahun 2007 yang Diubah Dengan UU No. 1 Tahun 2014 Tentang Pengelolaan Pesisir dan

17 Marsetio, "Mengembalikan Kejayaan Kelautan Indonesia", (Bogor: Penerbit Universitas Pertahanan, 2018), hlm. 144-146. 
Pulau-Pulau Kecil; serta (5) Undang-Undang Nomor 32 Tahun 2014 Tentang Kelautan.

Salah satu aspek penting dalam proses pemanfaatan dan pengelolaan kelautan Indonesia yaitu tata kelola kebijakan kelautan (ocean governance policy) yang terintegrasi dan berkelanjutan, yang dapat dijabarkan melalui bagan di bawah ini:
Visi kekelautanan di tahun 2045 meletakkan landasan komitmen untuk menjadikan Indonesia sebagai Poros Maritim Dunia di mana sektor kelautan diharapkan berkontribusi hingga 30\% dari PDB tahun 2045. ${ }^{18}$ Transportasi laut, pariwisata bahari, perikanan dan pertambangan diharapkan menjadi kontributor utama sektor ekonomi

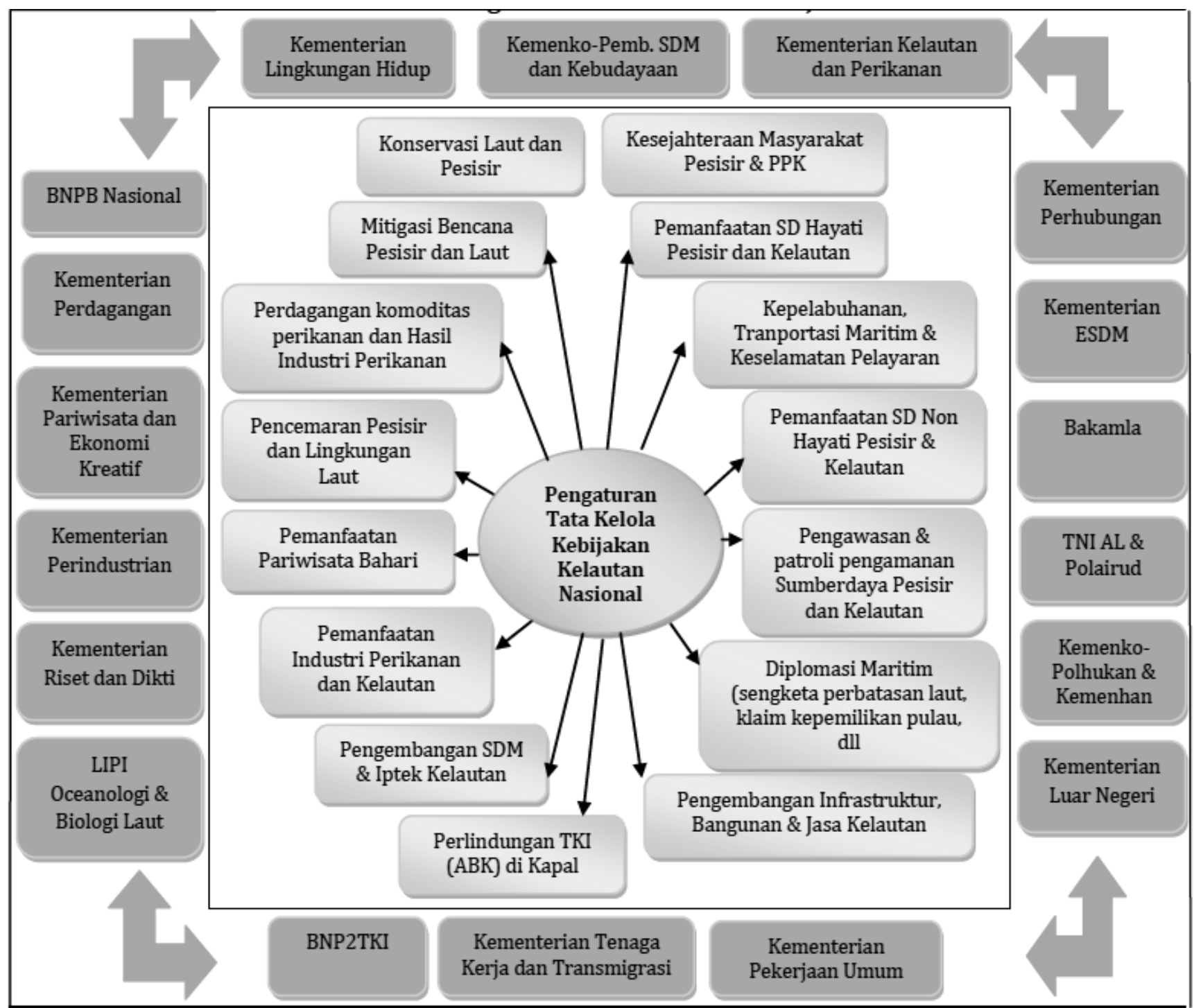

Gambar 5. Konsep "Mainstreaming Ocean Policy" kedalam Rencana Pembangunan Nasional (Sumber: Bappenas, 2014)

18 Lutfah Ariana, "Foresight Riset Kelautan Indonesia 2020-2045", Pusat Penelitian Oseanografi Lembaga Ilmu Pengetahuan Indonesia, 2017, hlm. 2, (http://oseanografi.lipi.go.id/haspen/Foresight\%20riset\%20 kelautan\%202020-2035_Final\%20Cetak.pdf) diakses 23 April 2019. 
kelautan selain bioteknologi dan eksplorasi sumber energi baru dari laut (seperti gelombang laut, arus laut, angin). Selain itu visi kelautan juga menekankan pembangunan kekuatan hankam dan budaya kelautan untuk mendorong kedaulatan wilayah yang kuat dan maju. Selanjutnya, jasa-jasa ekosistem laut, antara lain perubahan iklim, penyerapan karbon, siklus nutrient, perubahan suhu, perlindungan lingkungan pesisir diperkirakan akan semakin bernilai seiring perubahan karena tekanan terhadap lingkungan laut dan pesisir. Sektor strategis pembangunan kelautan dapat dijabarkan sebagai berikut:

\section{a. Transportasi dan Konektivitas Laut}

Transportasi laut telah digunakan sekitar 90\% perdagangan domestik dan internasional, sehingga kapasitas dan konektivitas dari pelabuhan sangat penting bagi penurunan biaya logistik dan pemetaan pertumbuhan nasional. ${ }^{19}$ Tol laut berupa konektivitas laut secara efektif dengan adanya kapal yang berlayar secara rutin dan terjadwal dari barat sampai timur Indonesia. Pemerintah telah menetapkan sasaran peningkatan 24 pelabuhan strategis untuk mendukung program Tol Laut. Peningkatan konektivitas nasional menekankan pada integrasi pembangunan Tol Laut untuk mewujudkan daya saing dan kedaulatan wilayah kepulauan Indonesia, menunjang pertumbuhan sektor pariwisata, serta mempersempit kesenjangan wilayah.

\section{b. Pariwisata Bahari}

Pariwisata bahari merupakan industri baru dan memiliki potensi yang signifikan sebagai pendorong pertumbuhan ekonomi nasional untuk meningkatkan pendapatan, peneriman devisa dan penciptaan lapangan pekerjaan. Hal yang perlu disadari dalam kebijakan pembangunan kelautan di sektor pariwisata adalah pengelolaan secara tepat dan bijaksana sehingga pembangunan tidak hanya berkonsentrasi pada bidang ekonomi tetapi juga mencakup bidang sosial, budaya dan lingkungan. Kunci dari keberhasilan tersebut adalah pembangunan pariwisata yang terpadu dan berkelanjutan. Tanpa adanya pengelolaan secara terpadu dan keberlajutan tidak mungkin ada pembangunan yang menghasilkan manfaat bagi semua pemangku kepentingan.

Pariwisata berkelanjutan fokus pada kebutuhan untuk memastikan bahwa konsep dapat diterapkan pada lingkungan manusia sertalingkungan fisik. Pariwisata berkelanjutan tidak hanya tentang pengendalian dan pengelolaan dampak negatif dari industri. Pariwisata menjadi posisi yang sangat istimewa untuk memberikan manfaat bagi masyarakat lokal, ekonomi dan sosial serta meningkatkan kesadaran dan dukungan untuk konservasi lingkungan. Pariwisata tidak menjadikan pembangunan dan perlindungan lingkungan sebagai dua sisi yang bertentangan dan bertolak belakang pada tataran implementasi, namun justru pariwisata dapat menyatukan dan memperkuat manfaat dari adanya pembangunan dan perlindungan lingkungan. Oleh karenanya kebijakan mutlak diperlukan untuk memperkuat manfaat tersebut. Kebijakan yang dihasilkan tidak hanya berorietasi pada keuntungan ekonomi saja tetapi juga memperkuat peluang pariwisata

19 Witjaksono, “Reborn Kelautan Indonesia”, (Jakarta: PT. Adhi Kreasi Pratama Komunikasi, 2017), hlm. 335-351. 
yang berorientasi pada budaya lokal dan lingkungan alam sehingga dihasilkan konsep pariwisata berkelanjutan yang berwawasan lingkungan.

\section{c. Perikanan Laut}

Sebagai negara kepulauan, laut Nusantara menyimpan potensi dan kekayaan perikanan yang sangat besar dan bernilai ekonomi tinggi. Data Kementerian Kelautan dan Perikanan mencatat, potensi ekonomi kelautan mencapai Rp. 3000 triliun dan yang tergarap baru Rp. 291,8 triliun. Selain itu laut Indonesia juga memiliki kekayaan berupa keanekaragaman hayati (biota) baik flora dan fauna laut sehingga laut Nusantara dikenal dunia sebagai "mega-biodiversity". Kekayaan flora di laut Nusantara antara lain mangrove, padang lamun, dan terumbu karang. Selain itu laut Nusantara juga menyediakan potensi lain seperti rumput laut, bunga karang, mutiara, kerang-kerangan (moluska).

Namun demikian potensi dan kekayaan yang berlimpah belum memberikan kontribusi yang signifikan bagi perekonomian nasional serta menyejahterakan masyarakat terutama nelayan. Data Sensus Pertanian Badan Pusat Statistik 2013 menunjukkan jumlah Rumah Tangga Nelayan sebesar 864.506 Rumah Tangga dan 7,9 juta penduduk pesisir hidup di bawah garis kemiskinan. Sehingga sektor perikanan mempunyai peranan yang penting dan strategis dalam pembangunan perekonomian nasional, terutama dalam meningkatkan perluasan kesempatan kerja, pemerataan pendapatan, dan peningkatan taraf hidup masyarakat.
Keberadaan Undang-Undang Nomor 31 Tahun 2004 Tentang Perikanan sebagaimana telah diubah dengan Undang-Undang Nomor 45 Tahun 2009 dan Undang-Undang Nomor 27 Tahun 2007 Tentang Pengelolaan Wilayah Pesisir dan Pulau-Pulau Kecil sebagaimana telah diubah dengan Undang-Undang Nomor 1 Tahun 2014 memberikan legalitas dan dasar eksistensi pengelolaan perikanan. Oleh sebab itu, kebijakan pembangunan kelautan di sektor perikanan diarahkan kepada lima hal, yaitu: ${ }^{20}$

1) Menjadikan perikanan tangkap sebagai salah satu andalan perekonomian nasional dengan membangkitkan industri perikanan dalam negeri;

2) Rasionalisasi, nasionalisasi dan modernisasi armada perikanan tangkap secara bertahap dalam rangka menghidupkan industri dalam negeri dan keberpihakan kepada perusahaan dalam negeri dan nelayan lokal;

3) Penerapan pengelolaan perikanan secara bertahap dan berorientasi kepada kelestarian lingkungan dan terwujudnya keadilan;

4) Mendorong Pemerintah Daerah agar lebih proaktif dan mengoptimalkan secara arif dan bijaksana seluruh potensi dan kemampuannya;

5) Rehabilitasi dan rekonstruksi daerahdaerah yang terkena bencana alam.

\section{d. Pertahanan dan Keamanan Laut}

Pembangunan ekonomi kelautan perlu didukung dengan sistem pertahanan dan keamanan yang kuat dan tangguh sehingga

20 Freddy Numberi, "Kembalikan Kejayaan Negeri Bahari” (Jakarta: PT. Bhuana Ilmu Populer, 2015), hlm. 153154. 
menjadi kekuatan strategis geopolitik dan geoekonomi. ${ }^{21}$ Sistem pertahanan dan keamanan integratif perlu dibangun sesuai dengan paradigma yang berkonsentrasi, keseimbangan darat, laut, udara yang tepat, maupun peralatan pertahanan keamanan untuk menjaga kedaulatan dan mempertahankan NKRI.

Dalam upaya pembangunan kelautan di sektor pertahanan dan keamanan, Indonesia membutuhkan kebijakan kelautan yang bersifat komprehensif, holistik dan integral. Keamanan kelautan memiliki pengertian kegiatan sipil maupun militer untuk mengurangi resiko dan melawan kegiatan illegal dan ancaman laut dengan cara penegakan kegiatan ilegal untuk melindungi kepentingan nasional. Adapun strategi yang dapat digunakan dalam rangka memperkuat dan mendukung kelautan Indonesia antara lain:22

1) Meningkatkan pemahaman dan penerapan tentang geopolitik kelautan Indonesia kepada para pemangku kepentingan. Tujuannya adalah memberikan kesadaran mengenai geopolitik dan geostrategis kelautan Indonesia agar dapat digunakan untuk memperkokoh sinergitas paradigma lintas sektoral.

2) Meningkatkan kebijakan kelautan nasional yang komrehensif, integral, dan holistik. Tujuan strategi ini adalah untuk mewujudkan agenda pemerintah dalam visi kekelautanan "mewujudkan Indonesia menjadi Poros Kelautan Dunia, yaitu menjadi sebuah negara kelautan yang maju, berdaulat, mandiri, kuat, serta mampu memberikan kontribusi positif bagi keamanan dan perdamaian kawasan dan dunia sesuai dengan kepentingan nasional".

3) Meningkatkan sinergitas paradigma lintas sektor di bidang kelautan antar pemangku kepentingan. Tujuan strategi ini adalah menumbuhkan kesadaran pemangku kepentingan, kementerian atau lembaga terkait di bidang kekelautanan baik pemerintah pusat maupun daerah tentang perlunya sinergitas paradigma lintas sektor dalam menangani berbagai permasalahan kelautan.

4) Mewujudkan stabilitas keamanan kelautan nasional guna mendukung pembangunan nasional. Tujuan strategi yang keempat adalah memberikan jaminan keamanan bagi para pengguna jasa laut di wilayah perairan Indonesia, sekaligus memberi dampak nyata terhadap stabilitas keamanan kelautan nasional.

5) Memberdayakan Bakamla sebagai institusi sipil nonmiliter (coast guard) dan merevisi kebijakan multi agency single function menjadi single agency multi function yang memiliki kewenangan penegakan hukum di laut. Tujuan strategi ini adalah untuk memberdayakan institusi sipil nonmiliter, Badan Keamanan Laut (Bakamla). Saat ini, beberapa instansi sipil nonmiliter bersifat multi agencies with single function belum single agencies with multi function sebagaimana badan keamanan laut (coast guard) di beberapa negara lain, yang

21 Aan Kurnia, "Facing Global Kelautane Fulcrum: Between Threats and Opportunities", (Jakarta: Petro Energy, 2017), hlm. 281-289.

22 Tri Sulistyaningtyas, dkk., "Sinergitas Paradigma Lintas Sektor di Bidang Keamanan dan Keselamatan Laut", (Jakarta: PT. Gramedia Pustaka Utama, 2015), hlm. 221-226. 
bertugas sebagai penegak hukum di laut dan berdampingan dengan institusi militer (navy) sebagai penegak kedaulatan negara dan hukum di laut.

\section{e. Pencemaran Laut, Pemanasan Global dan Perubahan Iklim}

Fungsi laut sebagai sumber kehidupan menjadi terganggu dikarenakan aktivitas manusia yang mencemari lingkungan laut, seperti transportasi laut, limbah dan plastik. Sumber pencemaran ini mengancam dan mengurangi jasa laut bagi kehidupan, baik sumber pangan, perikanan dan pariwisata terutama bagi masyarakat yang mengandalkan mata pencahariannya dari laut (nelayan, penggiat pariwisata, penduduk yang tinggal di kawasan pesisir). Sumber pencemaran dapat berupa bahan biologis, kimiawi, fisik atau energi yang pada tingkat tertentu dapat menganggu kehidupan organisme laut, sehingga dibutuhkan langkah pencegahan dan penanggulangan sumber dan jenis pencemaran melalui kebijakan penanganan limbah industri, rumah tangga, ataupun dari kegiatan pemanfaatan laut lainnya. Keberadaan Peraturan Pemerintah Nomor 21 Tahun 2010 Tentang Perlindungan Lingkungan Maritim menjadi pedoman dalam upaya untuk mencegah dan menaggulangi terjadinya pencemaran atau perusakan lingkungan laut akibat dari penyelenggaraan transportasi, serta keselamatan dan keamanan di laut. Perlindungan lingkungan laut dilakukan melalui kegiatan; 1) pencegahan dan penanggulangan pencemaran dari pengoperasian kapal, 2) pencegahan dan penanggulangan dari kegiatan kepelabuhan serta industri pembangunan atau pengerjaan kapal.

Selain itu, sebagai Negara Kepulauan Indonesia juga dihadapkan pada isu ancaman pemanasan global dan perubahan iklim. Pemanasan global memberikan dampak yang luar biasa bagi kehidupan di muka bumi, yaitu terjadinya kenaikan suhu rata-rata permukaan bumi. Faktor utama yang secara signifikan membuat temperatur bumi cenderung naik adalah adanya pertambahan populasi manusia di dunia dengan segala aktivitas yang dilakukannya. Penggunaan bahan bakar fosil, berkurangnya lahan hijau, dan efek industrialisasi menyebabkan semakin banyak gas buang yang memberi kontribusi bagi efek gas rumah kaca di bumi. Menurut laporan dari Intergovernmental Panel on Climate Change, dari tahun 1850 - 1899 hingga 2001 - 2005 terjadi kenaikan suhu dunia rata-rata sekitar $0,76^{\circ} \mathrm{C} .{ }^{23}$ Permukaan air laut selama periode 1961 hingga 2003 tercatat mengalami kenaikan rata-rata sebesar $1,8 \mathrm{~mm}$ per tahun. Dan hingga tahun 2080, diperkirakan kenaikan permukaan air laut akan meningkat menjadi sekitar 4,2 $\mathrm{mm}$ per tahun.

Salah satu masalah utama yang timbul karena peningkatan temperatur global ini adalah naiknya permukaan air laut, dimana masalah ini menjadi ancaman yang nyata bagi daratan yang ada di bumi, terutama di daerah pesisir dan pantai. Kenaikan permukaan air laut terhadap daerah pantai diantaranya akan menyebabkan adanya daratan yang hilang, kerusakan ekosistem di pantai, kerusakan infrastruktur dan bangunan di pantai, ancaman terhadap populasi penduduk di daerah pantai, yang semuanya tentu akan

\footnotetext{
Lihat laporan Intergovernmental Panel on Climate Change (IPCC), "Climate Change 2007 : Impacts, Adaption,
} and Vulnerability", 2007. 
menimbulkan kerugian materi yang sangat besar.

Meningkatnya pemanasan global di seluruh dunia sebagai akibat dari semakin tingginya emisi gas rumah kaca berdampak pada perubahan iklim di dunia. Usaha untuk menghadapi pemanasan global salah satunya adalah dengan melestarikan penyerap karbon. Selain hutan tropis yang mampu menyerap karbon, penelitian menunjukkan bahwa ekosistem laut dan pesisir, yang berupa mangrove, padang lamun, dan rawa pasang surut, memiliki kemampuan menyerap dan menyimpan emisi karbon jauh lebih baik daripada ekosistem hutan tropis di daratan. Sehingga langkah kebijakan yang dapat dikembangkan untuk mengatasi pemanasan global dan perubahan iklim adalah menyusun kebijakan karbon biru (blue carbon). Karbon biru memanfaatkan keberadaan hutan mangrove, padang lamun (ekosistem khas laut dangkal), rawa pasang surut dan ekosistem pesisir.

\section{f. Industri Kelautan}

Industri laut merupakan industri padat karya dan padat modal yang memiliki daya saing tinggi. Pengembangan industri kelautan tidak lepas dari peran industri galangan kapal sebagai salah satu kunci keberhasilan. ${ }^{24}$ Kementerian Perindustrian telah menyiapkan road map pembangunan industri perkapalan tahun 2012-2025. Sektor industri kelautan diharapkan mampu memproduksi dan mereparasi semua jenis kapal dari ukuran kecil sampai ukuran besar.

\section{g. Pertambangan dan Energi}

Indonesia merupakan salah satu negara dengan sumber daya alam terbesar, baik sumber daya terbarukan maupun yang tidak terbarukan. Sistem energi Indonesia saat ini masih didominasi penggunaan bahan bakar fosil yang ketersediaannya semakin lama semakin menipis. Sementara itu kebutuhan energi nasional kian hari terus meningkat. Disisi lain Indonesia memiliki kekayaan sumber daya dari energi terbarukan yang bersumber dari bawah laut. Akan tetapi sumber daya dari energi terbarukan belum dikelola dan dimanfaatkan secara maksimal. Energi laut (ocean energy) sebagai sumber energi alternatif dapat dimanfaatkan untuk menunjang kebutuhan masyarakat. Sumber energi laut diantaranya: energi pasang surut (tidal energy), energi panas laut (ocean thermal energy conversion), energi gelombang laut (wave energy), energi ganggang laut.

\section{Penutup}

Indonesia merupakan negara kepulauan terbesar di dunia yang memiliki 17.504 pulau dan luas perairan \pm 5.87 juta $\mathrm{km}^{2}$ menjadikan laut bermakna strategis sebagai pilar pembangunan nasional. Di masa lalu sejarah mencatat bahwa Indonesia pernah menjadi negara kelautan seperti pada kejayaan Kerajaan Sriwijaya dan Kerajaan Majapahit yang menjelajah sampai jauh ke Afrika Timur (Madagaskar) dan ke Pasifik Selatan. Saat ini Indonesia berusaha untuk membangkitkan

24 Didit Herdiawan, "Kedaulatan Pangan Kelautan: Dinamika dan Problematika", (Jakarta: Lembaga Ketahanan Nasional RI, 2016), hlm. 27. 
kembali kejayaan kelautan Nusantara melalui pembangunan kelautan Indonesia menuju Indonesia sebagai poros kelautan dunia. Oleh karenanya dibutuhkan kebijakan yang mendukung arah pembangunan kelautan Indonesia untuk mewujudkan kesejahteraan bagi rakyat Indonesia.

Pembangunan kelautan Indonesia membutuhkan tata kelola kebijakan yang baik dan berkelanjutan melalui pendekatan sosial budaya, ekonomi, serta politik, pertahanan dan keamanan. Penyelenggaraan pembangunan kelautan juga membutuhkan peran serta dan dukungan berbagai pihak sehingga dapat dilakukan secara holistik dan integral dengan memperhatikan kepentingan stakeholder. Visi kelautan Indonesia adalah mewujudkan Indonesia menjadi Poros Kelautan Dunia, yaitu menjadi sebuah negara kelautan yang maju, berdaulat, mandiri, kuat, serta mampu memberikan kontribusi positif bagi keamanan dan perdamaian kawasan dan dunia sesuai dengan kepentingan nasional.

Kebijakan Kelautan Indonesia dibangun berdasarkan 7 (tujuh) pilar, yaitu: 1) Pengelolaan sumber daya kelautan dan pengembangan sumber daya manusia; 2) Pertahanan, Keamanan, Penegakan Hukum, dan Keselamatan di Laut; 3) Tata kelola dan kelembagaan laut; 4) Ekonomi dan infrastruktur kelautan dan peningkatan kesejahteraan; 5) Pengelolaan ruang laut dan perlindungan lingkungan laut; 6) Budaya bahari; dan 7) Diplomasi kelautan. Sementara itu, rencana aksi kebijakan kelautan dijabarkan ke dalam 5 (lima) kluster prioritas, yaitu:1) batas kelautan, ruang laut, diplomasi kelautan, 2) Industri kelautan dan konektivitas laut, 3) Industri sumber daya alam dan jasa kelautan serta pengelolaan lingkungan laut,
4) Pertahanan dan keamanan laut, 5) budaya bahari.

\section{Daftar Pustaka}

\section{Buku}

Herdiawan, Didit, Kedaulatan Pangan Kelautan: Dinamika dan Problematika, (Jakarta: Lembaga Ketahanan Nasional RI, 2016)

Kurnia, Aan, Facing Global Kelautane Fulcrum: Between Threats and Opportunities, (Jakarta: Petro Energy, 2017)

Marsetio, Mengembalikan Kejayaan Kelautan Indonesia, (Bogor: Penerbit Universitas Pertahanan, 2018)

Marzuki, Peter Mahmud, Penelitian Hukum (Edisi Revisi, Jakarta: Kencana Prenada Media, 2014)

Numberi, Freddy, Kembalikan Kejayaan Negeri Bahari, (Jakarta: PT. Bhuana IImu Populer, 2015)

Prasetia, Ade, Ekonomi Kelautan Indonesia, (Yogyakarta: Diandra Kreatif, 2016)

Sulistyaningtyas,Tri, Susanto dan Dicky R. Munaf, Sinergitas Paradigma Lintas Sektor di Bidang Keamanan dan Keselamatan Laut, (Jakarta: PT. Gramedia Pustaka Utama, 2015)

Supandi, Ade, Fondasi Negara Kelautan, (Jakarta: Yayasan Pustaka Nasution, 2018)

Witjaksono, Reborn Kelautan Indonesia, (Jakarta: PT. Adhi Kreasi Pratama Komunikasi, 2017)

\section{Makalah/Artikel/Prosiding/Laporan/Hasil Penelitian}

Dahuri, Rokhmin, "Road Map Pembangunan Kelautan Untuk Mengembangkan Daya Saing dan Pertumbuhan Ekonomi Berkualitas Menuju Indonesia Yang Maju, Adil-Makmur, dan Berdaulat" (makalah disampaikan pada acara Simposium Nasional Jalan Kemandirian Bangsa, 2014)

Intergovernmental Panel on Climate Change (IPCC) "Climate Change 2007 : Impacts, Adaption, and Vulnerability", (2007)

Kementerian Kelautan dan Perikanan Republik Indonesia "Laporan Kinerja Kementerian Kelautan dan Perikanan", (2016)

Sulistiyono, Singgih Tri, "Paradigma Maritim Dalam Membangun Indonesia: Belajar dari Sejarah", Lembaran Sejarah, Volume 12 Nomor 2 Oktober (2016) 
Tim Harmonisasi Kementerian PPN/Bappenas, Departemen Kelautan dan Perikanan dan Departemen Hukum dan Hak Asasi Manusia bekerjasama dengan Mitra Pesisir "Menuju Harmonisasi Sistem Hukum Sebagai Pilar Pengelolaan Wilayah Pesisir Indoensia", Laporan, (2005)

\section{Internet}

Kedeputian Bidang Sumber Daya Alam dan Lingkungan Hidup Badan Perencanaan Pembangunan Nasional "Konsep Mainstreaming Ocean Policy Ke Dalam Rencana Pembangunan Nasional", 2014, https:// www.bappenas.go.id/files/3114/6225/6899/ LAPORAN_AKHIR_OCEAN_POLICY.pdf, (diakses 20 April 2019)

Lutfah Ariana, "Foresight Riset Kelautan Indonesia 2020-2045", Pusat Penelitian Oseanografi Lembaga IImu Pengetahuan Indonesia, 2017, http://oseanografi.lipi.go.id/haspen/ Foresight $\% 20$ riset $\% 20$ kelautan\%202020-
2035_Final\%20Cetak.pdf, (diakses 20 April 2019)

\section{Peraturan Perundang-Undangan}

Undang-Undang Nomor 17 Tahun 1985 Tentang Pengesahan Konvensi Perserikatan BangsaBangsa Tentang Hukum Laut (United Nations Convention on the Law of the Sea/UNCLOS 1982)

Undang-Undang Nomor 31 Tahun 2004 Tentang Perikanan sebagaimana telah diubah dengan Undang-Undang Nomor 45 Tahun 2009

Undang-Undang Nomor 27 Tahun 2007 Tentang Pengelolaan Wilayah Pesisir dan Pulau-Pulau Kecil sebagaimana telah diubah dengan Undang-Undang Nomor 1 Tahun 2014

Undang-Undang Nomor 32 Tahun 2014 Tentang Kelautan

Peraturan Presiden Nomor 115 Tahun 2015 Tentang Satuan Tugas Pemberantasan Penangkapan Ikan Secara Ilegal (Illegal Fishing)

Peraturan Presiden Nomor 16 Tahun 2017 Tentang Kebijakan Kelautan Indonesia 